\title{
PENATALAKSANAAN PEMBUATAN LOGMAR CHART DENGAN MENGGUNAKAN SIMBOL
}

\author{
Jaja Muhamad Jabbar'), Nabila Leviana Permatasari ${ }^{2)}$ \\ ${ }^{1}$ Dosen Program Studi Diploma Tiga Opthometri STIKes Dharma Husada Bandung \\ ${ }^{2}$ Mahasiswa Program Studi Diploma Tiga Opthometri STIKes Dharma Husada Bandung \\ jabbar_muhammad20@yahoo.co.id
}

\begin{abstract}
Abstrak
Berdasarkan studi pendahuluan di Desa Cipanjalu Kecamatan Cilengkrang Kabupaten Bandung, chart untuk pemeriksaan Low Vision hanya mempunyai tipe yang menggunakan huruf Alphabet dan $E$ Chart.

Tujuan penelitian ini adalah untuk membuat Instrumentasi Refraksi di Laboratorium Refraksi Optisi STIKes Dharma Husada, berupa Chart Simbol dengan besaran simbol yang baik dan benar sesuai dengan ketentuan yang berlaku. Metode penelitian yang digunakan adalah eksperimental.

Populasi dalam penelitian ini terdiri dari 10 orang diantaranya, anak berusia 3-4 tahun, orang tua, dan para ahli Refraksi Optisi.

Sampel yang di gunakan dalam penelitian ini adalah simple random sampling dengan menggunakan sistem sampling jenuh dari 4 orang anak berusia 3-4 tahun, orang tua sebanyak 4 orang, dan 2 ahli Refraksi Optisi untuk melakukan pengujian terhadap LogMAR Chart, dengan pengulangan sebanyak 5 kali.

Hasil peneitian dari uji banding Chart Simbol, LogMAR Chart (E Chart), dan Visus Projector terhadap 8 responden dengan pengulangan 5 kali didapatkan secara keseluhan, responden tersebut dapat menyebutkan arah dan symbol atau gambar dengan baik dan benar.

Kesimpulan dari penelitian ini adalah sesuai hasil tabel kesalahan relatif dapat disimpulkan bahwa, alat peneliti layak untuk digunakan. Chart Simbol dapat dibuat dengan besaran yang sesuai dengan ketentuan dan dapat digunakan sebagai alat pengganti LogMAR Chart dalam bentuk $e$ chart.
\end{abstract}

Kata Kunci : Chart Simbol, LogMAR Chart

\section{PENDAHULUAN}

Mata adalah salah satu sumber informasi yang paling penting bagi semua manusia. Penglihatan merupakan hadiah yang tak ternilai yang diberikan oleh Tuhan. Namun bila terjadi gangguan pada mata, hal tersebut dapat mengganggu aktifitas dan kehidupan manusia pada umumnya. Ada beberapa kelainan yang dapat mengganggu penglihatan, diantaranya adalah Miopia, Hipermetropia, Astigmat, Presbiopia, Katarak, Glaukoma, Kebutaan, dan Low Vision.
Low Vision dapat terjadi akibat keturunan atau penyakit yang didapat dari kebiasaan buruk seseorang. Penyebab utama Low Vision adalah degenerasi makula, glaukoma, retinopati diabetik, dan katarak, serta karena penyakit langka. Pengobatan dan penanganan dini dapat lebih efektif, dan memungkinkan orang mempertahankan penglihatan .

Semua penderita Low Vision membutuhkan alat bantu untuk menunjang penglihatannya. Diantaranya; hand magnifiers, stand magnifiers, iluminated magnifiers, dan telescope. Sebelum mendapatkan alat bantu Jurnal Penelitian Kesehatan STIKes Dharma Husada Bandung 
JURNAL SEHAT MASADA VOLUME XVI tersebut, pasien terlebih dahulu melakukan pemeriksaan untuk mengetahui visus dasar atau koreksi visus maksimal setelah dilakukan tahapan pemeriksaan lanjutan oleh seorang Refraksionis Optisien, dengan menggunakan chart yang bernama LogMAR Chart.

Profesi Refraksionis Optisien sangat membutuhkan LogMAR Chart untuk melakukan pemeriksaan kepada pasien tuna aksara. Namun cara memperoleh LogMAR Chart tersebut cukup sulit, bias diperoleh melalui pembelian online namun perlu waktu pengiriman cukup lama.

Dikarenakan masih ada tuna aksara yang perlu melakukan pemeriksaan visus, penulis memiliki keinginan untuk membuat penelitian "Penatalaksanaan Pembuatan Chart Simbol". Yang diharapkan dapat membantu profesi Refraksionis Optisien dalam pemeriksaan pasien Low Vision dengan menggunakan alat bantu yang mudah dicari didalam negeri, praktis, murah dan mudah dalam pemeriksaan untuk seorang pasien yang tidak bisa mengeja huruf.

\section{METODOLOGI}

Metode penelitian berupa eksperimen, dan observasi. Peneliti melakukan ekspreimen pembuatan alat chart symbol. Chart symbol diujicobakan kepada anak usia 3-5 tahun, orang tua san para ahli refraksi Optisi.

Observasi dilakukan untuk pengumpulan data dengan melakukan pengamatan secara langsung kepada responden penelitian untuk mencari perubahan atau hal-hal yang akan di teliti. Dalam metode observasi ini, instrumen
NOMOR 1 Januari 2022

ISSN : 1979-2344

yang dapat digunakan adalah: penentuan visus dasar untuk mengukur hasil akhir dari hasil pemeriksaan LogMAR Chart tersebut dan penentuan visus dilakukan sesuai SOP.

\section{A. Penatalaksanaan Pembuatan}

Alat

\section{LogMAR Chart Simbol}

1) Persediaan alat-alat yang dibutuhkan sebelumnya dalam pembuatan alat Chart Simbol yang diperlukan antara lain:

a) Kertas berukuran A1 dengan nama bahan Art Paper dengan jumlah 2 lembar dengan lebar $66 \mathrm{~cm}$ x 62 $\mathrm{cm}$.

b) Pisau pemotong kertas otomatis

2) Teknik pembuatan Chart Simbol

a) Design alat dirancang dengan aplikasi grafik berbasis computer yaitu Corel Draw untuk membuat besaran objek Chart Simbol.

- Chart Simbol barisan pertama dengan ukuran pada optotype dengan gambar Lingkaran, Segitiga, Bulan Sabit, Segitiga, Belah Ketupat di tempatkan secara acak yang masing-masing gambar berukuran $58,20 \mathrm{~mm}$. Dengan keterangan visus 1.0 dalam LogMAR.

- Chart Simbol barisan kedua dengan ukuran pada optotype dengan gambar Lingkaran, Segitiga, Bulan Sabit, Segitiga, Belah Ketupat di tempatkan secara acak yang masing-masing gambar berukuran $46,23 \mathrm{~mm}$. 
dalam LogMAR.

- Chart Simbol barisan kedua dengan ukuran pada optotype dengan gambar Lingkaran, Segitiga, Bulan Sabit, Segitiga, Belah Ketupat di tempatkan secara acak yang masing-masing gambar berukuran 36,72 $\mathrm{mm}$. Dengan keterangan visus 0.8 dalam LogMAR.

- Chart Simbol barisan kedua dengan ukuran pada optotype dengan gambar Lingkaran, Segitiga, Bulan Sabit, Segitiga, Belah Ketupat di tempatkan secara acak yang masing-masing gambar berukuran 29,17 $\mathrm{mm}$. Dengan keterangan visus 0.7 dalam LogMAR.

- Chart Simbol barisan kedua dengan ukuran pada optotype dengan gambar Lingkaran, Segitiga, Bulan Sabit, Segitiga, Belah Ketupat di tempatkan secara acak yang masing-masing gambar berukuran 23,17 $\mathrm{mm}$. Dengan keterangan visus 0.6 dalam LogMAR.

- Chart Simbol barisan kedua dengan ukuran pada optotype dengan gambar Lingkaran, Segitiga, Bulan Sabit, Segitiga, Belah Ketupat di tempatkan secara acak yang masing-masing gambar berukuran $18,40 \mathrm{~mm}$. dalam LogMAR.

- Chart Simbol barisan kedua dengan ukuran pada optotype dengan gambar Lingkaran, Segitiga, Bulan Sabit, Segitiga, Belah Ketupat di tempatkan secara acak yang masing-masing gambar berukuran 14,62 $\mathrm{mm}$. Dengan keterangan visus 0.4 dalam LogMAR.

- Chart Simbol barisan kedua dengan ukuran pada optotype dengan gambar Lingkaran, Segitiga, Bulan Sabit, Segitiga, Belah Ketupat di tempatkan secara acak yang masing-masing gambar berukuran 11,61 $\mathrm{mm}$. Dengan keterangan visus 0.3 dalam LogMAR.

- Chart Simbol barisan kedua dengan ukuran pada optotype dengan gambar Lingkaran, Segitiga, Bulan Sabit, Segitiga, Belah Ketupat di tempatkan secara acak yang masing-masing gambar berukuran 9,22 $\mathrm{mm}$. Dengan keterangan visus 0.2 dalam LogMAR.

- Chart Simbol barisan kedua dengan ukuran pada optotype dengan gambar Lingkaran, Segitiga, Bulan Sabit, Segitiga, Belah Ketupat di tempatkan secara acak yang masing-masing gambar berukuran 7,33 $\mathrm{mm}$. 
Dengan keterangan visus 0.1

percetakan di program dengan

dalam LogMAR.

- Chart Simbol barisan kedua dengan ukuran pada optotype dengan gambar Lingkaran, memasukkan desain alat yang dibuat dengan Corel Draw lalu bahan Art Paper A1 dengan lebar $66 \mathrm{~cm} \times 62 \mathrm{~cm}$.

Segitiga, Bulan Sabit, Segitiga,

c) Perakitan alat

Belah Ketupat di tempatkan secara acak yang masing-masing gambar berukuran 5,82 $\mathrm{mm}$. Dengan keterangan visus 0.0 dalam LogMAR

- Chart Simbol barisan kedua dengan ukuran pada optotype dengan gambar Lingkaran, Segitiga, Bulan Sabit, Segitiga, Belah Ketupat di tempatkan secara acak yang masing-masing gambar berukuran 4,62 $\mathrm{mm}$. Dengan keterangan visus -0.1 dalam LogMAR

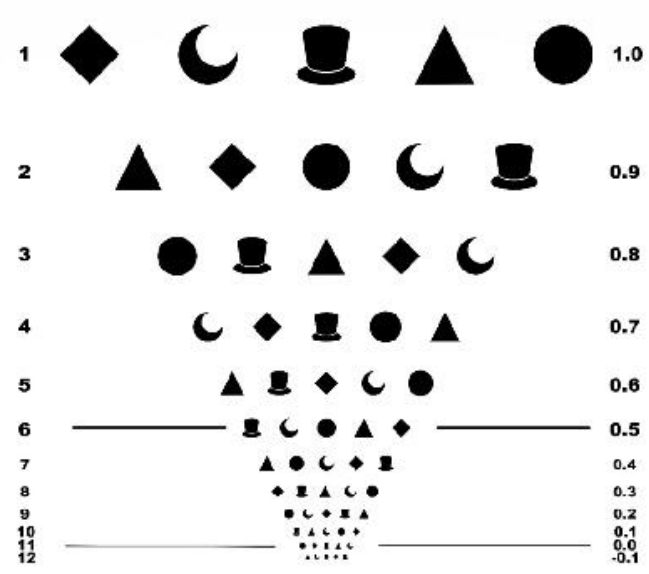

Gambar 1 Chart Simbol

b) Proses Percetakan

Pelaksanaan percetakan desain alat dilakukan di percetakan dengan mesin percetakan otomatis. Mesin

Setelah melalui beberapa tahap perancancangan desain,percetakan alat. Alat dipotong dengan cara otomatis mengunakan pisau pemotong kertas otomatis.

B. Standard Operating Procedure of LogMAR Chart. ( Canadian Longitudinal Study on Aging - Vision Visual Acuity, 2015)

1) Mulailah dengan 'mata kanan', mata kiri di tutup menggunakan occluder sehingga mata kanan pasien bisa melihat objeknya. CATATAN : Jika pasien tidak dapat membaca huruf perbaris secara lengkap namun bisa membaca sebagian maka masukan rumus ( baris yang terbaca $+0,02 \mathrm{x}$ huruf yang tidak terbaca).

2) Jarak pemeriksaan yaitu 4 meter, 2 meter, dan 1 meter. Bila pasien tersebut tidak bisa membaca huruf atau simbol tersebut dalam jarak 4 meter, maka chart tersebut di majukan ke jarak 2 meter. Bila pasien tidak dapat membaca huruf atau simbol tersebut dalam jarak 2 meter, maka chart tersebut di majukan ke jarak 1 meter.

3) Ulang pemeriksaan dengan menggunakan mata kiri, mata kanan di tutup menggunakan occluder. 
JURNAL SEHAT MASADA VOLUME XVI

4) Tulis visus pasien dengan benar agar mendapat alat bantu pembesaran yang sesuai dengan apa yang diderita.

\section{HASIL DAN PEMBAHASAN}

Hasil dari uji kelayakan alat yang dilakukan oleh 2 orang ahli terhadap standar prosedur operasional, desain alat dan besaran objek alat Chart Simbol peneliti adalah lebih melengkapi standar prosedur operasional dan untuk desain gambar dan besaran objek sudah memenuhi syarat untuk dipergunakan sebagai alat pemeriksaan Visual Acuity.

Berdasarkan dari tabel kesalahan relatif pembacaan visus $\mathrm{A}$ dan $\mathrm{B}$ dapat diketahui bahwa alat yang dibuat oleh peneliti jika dibandingkan dengan LogMAR Chart Pabrikan dan Visus Projector didapatkan hasil pengukuran di alat A sebesar; Visus Pabrikan $12,5 \%$, Visus Projector $10 \%$,Visus Buatan 7,5\%, dan di alat B sebesar; Visus Pabrikan 20 $\%$, Visus Projector $20 \%$, Visus Buatan 2,5\%. Dari data tersebut dapat kita simpulkan bahwa alat yang dibuat peneliti lebih baik jika dibandingkan dengan alat pabrikan dan visus projector.

Dari hasil alat Chart Simbol, LogMAR Chart (E Chart), dan Visus Projector terhadap 8 responden dengan pengulangan 5 kali didapatkan beberapa hasil yang berbeda antara alat Chart Simbol, LogMAR Chart (E Chart), dan Visus Projector dimana beberapa responden terbalik menyebutkan arah pada e chart, salah menyebutkan gambar pada visus projector, dan salah menyebutkan gambar pada Chart Simbol. Kesalahan tersebut terjadi
NOMOR $1 \quad$ Januari $2022 \quad$ ISSN : 1979-2344

akibat responden tidak fokus dalam pemeriksaan, suasana pemeriksaan visus kurang menyenangkan cenderung membosankan, dan tidak melakukan pemeriksaan objektif untuk anak dengan mengunakan tetes cyclopegic (obat tetes untuk melumpuhkan akomodasi pada mata). Namun secara keseluhan, responden tersebut dapat menyebutkan arah dan symbol atau gambar dengan baik dan benar.

\section{KESIMPULAN}

Hasil tabel kesalahan relatif pembacaan visus dari alat $\mathrm{A}$ adalah visus pabrikan sebesar $12,5 \%$, visus projector sebesar $10 \%$, dan visus buatan sebesar 7,5\%. Hasil tabel kesalahan relatif pembacaan visus dari alat $\mathrm{B}$ adalah visus pabrikan sebesar $20 \%$, visus projector sebesar 20\%, dan visus buatan sebesar 2,5\% Sesuai hasil tabel kesalahan relatif dapat disimpulkan bahwa, alat peneliti layak untuk digunakan,

Chart Simbol dapat dibuat dengan besaran yang sesuai dengan ketentuan tabel 2.1, tabel 4.2, dan dapat digunakan sebagai alat pengganti $\log M A R$ Chart dalam bentuk $e$ chart.

\section{DAFTAR PUSTAKA}

A. Jonathan Jackson, James S. Wolffsohn. LowVision Manual. China: Butterworth Heinemann Elsevier; 2007

Arsyad, A, Media Pembelajaran, edisi 1. Jakarta: PT. Raja Grafindo Persada;2002.

Dr. Hj. Khadijah, M.Ag. Pengembangan Kognitif Anak Usia Dini. Medan: Perdana Publishing (Kelompok Penerbit Perdana Mulya Sarana) Anggota Ikatan Penerbit Indonesia (IKAPI); 2016 
Ian L. Bailey, Jan E. Lovie-Kitchin. Visual AcuityTesting.From The Laboratory to The Clinic. Elsevier;2013

Macnaughtan Jane. Eye Essentials Low Vision Assessment. China : Elsevier; 2005

Mitchell M. Scheiman, O.D., M.S., Principal Author Catherine S. Amos, O.D. Elise B. Ciner, O.D. Wendy Marsh-Tootle, O.D. Bruce D. Moore, O.D. Michael W. Rouse, O.D., M.S. Pediatric Eye And Vision Examination. Lindbergh Blvd., St. Louis: American Refraksi Optisic Association 1994, 2002

Notoatmojo, Prof. Dr. Soekidjo. Metodologi Penelitian Kesehatan. Jakarta : PT. Rineka Cipta; 2010

Nurchaliza Hazaria Siregar. Low Vision. Medan: Depart. Ilmu Kesehatan Mata FK Univ.Sumatra Utara; 2009

Vision 2020 di Indonesia, 2017. https://perdami.id/vision-2020-indonesia/ (Diakses Pada Tanggal 10-februari-2018; 7:24)

World Sight Day dan Vision 2020 di Indonesia.

https://lifestyle.kompas.com/read/2010/10 /19/07082437/world.sight.day.dan.vision. 2020.di.indonesia (Diakses Pada Tanggal 10-februari-2018; 7:45) 